\title{
Development of Smart Paper Engineering (SMART- PEN) Thematic Media using the RADEC Model to Train Creative Skills and Critical Thinking Elementary School Students
}

\author{
Nanang Rosid Abidin ${ }^{1}$, Subuh Anggoro ${ }^{2}$ \\ \{ nanangrusyd@gmail.com \} \\ ${ }^{1}$ SD Muhammadiyah Sudagaran Wonosobo \\ ${ }^{2}$ Universitas Muhammadiyah Purwokerto
}

\begin{abstract}
Literacy competence is essential so that Indonesian human resources can compete. And 21st-century skills that students must have, namely collaboration, communication, critical thinking, and creativity (4C). The purpose of this development research is to improve the literacy and $4 \mathrm{C}$ skills of SD Muhammadiyah Sudagaran Wonosobo students by using thematic learning tools in the form of Smart Paper Engineering (Smart-Pen) Thematic Media based on the (Read, Answer, Discuss, Explain, Create) RADEC Model. The research model used is ADDIE(Analyze, Design, Develop, Implement, and Evaluate) which was developed by Dick and Carry. Based on the hypothesis that the SMART-PEN thematic media design with the RADEC model is valid and effective in training elementary school students' 4C skills. The results of the research on Smart Paper Engineering (Smart-Pen) Thematic Media Development Using the Radec Model to Train Critical Thinking Skills students got a score of $87.10 \%$ with very good criteria for developing critical thinking and $80.65 \%$ training creative thinking with good criteria. The impact of Smart-Pen for students are 1) Students have critical thinking skills; 2) Students are more enthusiastic about learning; 3) Students can become creative directors and find specifications for in-depth learning media; 4) Learners can innovate; 5) as a reference and development media for teachers in conducting learning 6) Smart-pen is effectively used in training critical and creative thinking skills.
\end{abstract}

Keywords: SMART-PEN, RADEC, Literacy, 4C, Elementary School Students

\section{Introduction}

Indonesian education is starting a new chapter with the Minimum Competency Assessment which, will be socialized in 2020. The two competencies measured are reading literacy and numeracy[1]. This competence is essential for Indonesian students to be able to compete with other countries. Mastery of 21 st-century skills is different from last century skills[2].Areti [3] in, his research argues, 21st-century competence requires learning skills and motivation. These skills include creativity, critical thinking, communication, and collaboration skills. In the world of education, it is no longer oriented to the cognitive domain but has trained the meaningful skills needed in everyday life, and this is a challenge for educators always to learn.

Educators need to take an important role to innovate and be creative in making appropriate learning media so that they can support the learning process, this cannot be separated from the ability of teachers to continue learning so that students are expected to be able to 
compete in the 21 st century era by practicing $4 \mathrm{C}$ skills as well as reading and literacy culture. [4]. The creativity of educators is the key to success in training 4C skills for students through learning innovations, both models and media.

Conditions in the field do not show any awareness to adapt education to the times. This can be seen from the results of a study in whichin 2012 Indonesia was ranked 64th out of 65 countries. In 2015 it was ranked 64th out of 72 countries, which makes Indonesia still at the level of low ability when viewed from the cognitive aspect (knowing, applying, and reasoning) [5]. That means learning in Indonesia still does not include 21st century thinking skills[6]. This note the importance of creating innovative models and learning media to train elementary school students' 4C skills.

This happened in SD Muhammadiyah Sudagaran Wonosobo, not all teachers are ready for the changes and challenges of the 21 st century, it is proven that media innovation and learning models have not been maximized so that students are not accustomed to thinking critically when learning takes place, have not developed creativity, still lack collaboration and have not maximized effective ways of communicating well.

Answering these challenges where 4C competencies and literacy are needed, an easy learning model is needed. The RADEC (Read Answer Discuss Explain and Create) model is one of the recommendations for a learning model that can be applied because it is easy to understand and do [7].

Media comes from Latin, in the plural form of the word medium, which means intermediary or introduction. understanding of media is everything that can be used to convey messages from sender to recipient[8]. Mediais a means, all forms of communication tools that can be used to convey learning materials between educators and students and can also stimulate students' thoughts, feelings, concerns, and abilities to encourage the achievement of an active, innovative, creative, effective, and fun learning process. From these various opinions, it can be concluded that learning media are used to channel information in achieving learning objectives.[9]

Thematic learning can be interpreted as learning activities by integrating the material of several subjects into one theme or learning topic. thematic learning attempts integrate knowledge, skills, learning values or attitudes, and creative thinking with one theme[10].

Thematic learning is chosen at the elementary school level because it has exciting characteristics for the development of student learning. material in thematic learning should use materials that can be combined. Thematic learning where, subject competencies are tied into a theme then becomes learning material for students to be applied in 2013 curriculum learning[11].

Smart-Pen can be interpreted as a smart paper engineering or a form of paper creation combined with an internet connection via a qr code.Smart-Pen in research and development is a paper-based learning media or better known as paper engineering combined with a laptop or smart device with the Android operating system. Paper engineering is a cutting or cutting technique, such as making pop-ups in books or moving cards. This creation can make paper engineering elegant in an attractive 3D form [12]. 3D or 3 Dimensions is an object or space with length, width and height and has a shape. Not only in 3D mathematics, but also in the fields of graphics, art, animation, computers, and others[13].

Smart-Pen allows interaction between students and paper engineering media by manipulating objects contained in laptops or smart devices. The benefits of gadgets or laptops in this learning media are displaying text, images, animations, videos, games, and evaluations related to learning materials. In principle, students will interact with the Smart-Pen related to the material as a knowledge search activity contained in applications that have been embedded 
in Android-based devices or laptops. Smart-Pen has educational game features including 1) Kahoot, this platform is a digital gamification tool for students through questionnaires, multiple choice this application can be used either on the web with a laptop or smart device format[14], the advantages of this application is that it is easy and fun to play. 2) Education. It is an engaging online learning game[15]for students. 3) Smart Apps Creator, an application for creating learning games because it has advantages (SmartAppsCreator, 2020), including a) It does not require programming skills, so it is easy to use it as a learning medium; b) Applications can be implemented on various platforms ranging from android, IOS, web, and others; c) Can apply animation to the application design that will be developed according to the creativity of the developer based on needs; d) Support various kinds of formats, mp3, mp4, png, jpg, gif, pdf and others; e) Integrated web services make applications more functional[16].

The choice of the RADEC model in this research, apart from with an easy syntax, this model is based on the Indonesian education system which requires students to understand many scientific concepts in a limited time. This model is the latest breakthrough in the world of education and can train 21 st century competencies, character, and literacy accompanied the preparation for exams held by schools or universities[17].

Critical thinking is one of the life skills that need to be trained and developed in the educational process. With the ability to think, a person can observe and find solutions to all the problems encountered in his life. Therefore, in the 21 st century thinking skills are important skills that must be possessed by every graduate at every level of education. 6 elements in critical thinking which is abbreviated as FRISCO:

1) F (Focus): focuses on the issue or question at hand to make a decision about what to believe and understand.

2) R (Reason): have a reason to support or reject a decision made based on the situation and relevant facts.

3) I (Inference): make a convincing conclusion with reasons. An important part of this step is to identify assumptions by looking for solutions, considering interpretations of the situation and existing evidence.

4) S (Situation): understand and keep the situation in mind to help clarify the questions in the focus step and know the meaning of important or key terms, and understand the relevant parts as support.

5) $\mathrm{C}$ (Clarity): explains the meaning or terms used in conveying the reasons.

6) (Overview): not rash always review and thoroughly examine the decisions taken.[19]

Creativity is one of the important skills that must be mastered and is the key to effective learning in the 21 st century. This skill can be fostered by teachers and the learning environment by encouraging open-ended questions, and the emergence of new ideas, and not being shy about learning from mistakes and failures. Like other skills, creativity and innovation can be developed through practice and over time. In building effective creative skills, students must begin to learn to [19]:

1) Brainstorming techniques for generating ideas and creating new and meaningful ideas.

2) Perfecting, analyzing, and evaluating ideas then improving and maximizing creative efforts.

3) Build creative ideas to make a real and useful contribution to the field where the innovation is carried out 
Based on the background of the problem, the researcher will examine (1) How is the process of implementing smart paper engineering (SMART-PEN) thematic learning media with the RADEC model to train elementary school students' 4C skills? (2) How is the effectiveness and convenience of smart paper engineering (SMART-PEN) thematic learning media with the RADEC model to train elementary school students' 4C skills?

\section{Method}

\section{Research design}

The ADDIE model developed aims to design a learning system. The following is an explanation of the stages of the ADDIE model developed in creating a learning system[20]: Analysis

This stage of the activity analyze the need for the development of thematic media designs and the feasibility and requirements for developing thematic media designs. The result of thematic media design begins with problems in the creation of learning media applied. Problems occur because the media in the plan is not relevant to the needs of students, the learning environment, technology, and the characteristics of the knowledge, skills of students and teachers.

\section{Design}

In designing thematic learning media, the design stage has similarities with creating teaching and learning activities. This activity is a systematic process starting from setting learning objectives, creating teaching and learning scenarios, designing learning tools, designing learning materials and evaluating learning outcomes. The design of this learning media is still conceptual and will underlie the following media development process.

\section{Development}

Development in the ADDIE model contains activities for the realization of product or media designs. The completion of the design concept stage that has been compiled is implemented into a product ready for testing. At this stage, the researcher carried out the activity of making a blueprint from the Outline of Media Content (GBIM) and Outline of Material (JM) and lesson plans with the RADEC learning model and evaluation instrument in the form of a 4C rubric. Next is the expert validation stage to get suggestions, improvements, and recommendations and the feasibility of the media design that is being developed.

\section{Implementation}

At this stage, the implementation of thematic media design and development in real situations, namely in the classroom. During performance, the media designs developed were applied to actual conditions. After the application of the media, an initial evaluation is carried out to provide feedback on the application of the following media, the objectives are as follows:

1. Guiding students to achieve learning objectives.

2. Ensure the occurrence of problem-solving to address student gaps.

3. Produce competency results to train the required $4 \mathrm{C}$ skills.

\section{Evaluation}

The evaluation used a limited test conducted in one elementary school with three tests, namely trial 1 , trial 2 , and trial 3 . The experimental method used was a single one shot case study model. This method uses the paradigm that a group is given treatment and then the results are observed[21]. 


\section{Data Analysis}

Analysis of SMART-PEN Thematic Media Design with RADEC model to Train 4C Skills in Elementary School Students. The development of instructional media design requires assessment. The assessment was carried out by validators, which consisted of expert validators of learning media and materials and classroom teacher practitioners in research schools. The assessment results collected will be analyzed quantitatively and qualitatively, to measure the level of validity of thematic learning media products. The data collection technique used is quantitative descriptive data using a Likert scale as shown in the table.

In this study, the design of the learning media developed was judged to be valid by expert validators and practitioners, at least the criteria were entirely useful. If the final result is accurate enough, then the learning media developed is considered feasible for learning to practice 4C skills.[22]

\section{Analysis of the Effectiveness of SMART-PEN Thematic Media with the RADEC model to Train Creative Skills And Critical Thinking in Elementary School Students}

Test the effectiveness of SMART-PEN thematic media to measure how far the target, quality, time has been achieved. In training critical thinking skills and creativity. The indicators include 1) information and findings; 2) interpretation and analysis; 3) build arguments; 4) design ideas; 5) creative production. The format of the instrument developed is in the form of a table consisting of performance aspects, student performance criteria, assessment indicators, and time information.[23].

\section{Results and Dicussion}

\section{Analysis}

At this stage the researcher analyzes the need for the development of thematic learning media and analyzes its feasibility. The development of new learning media begins by looking at the problems in the application of learning media and previous learning models. Conventional learning outcomes on the material provided by the teacher have not been absorbed optimally. The researcher uses the development of the Smart-Pen thematic learning media based on the process.

At this stage, the activities carried out are analyzing the need for the development of thematic media design and analyzing the feasibility and needs of developing thematic media design. The development of thematic media design begins with problems in the design of learning media that have been applied. Problems occur because the media in the design is not relevant to the needs of students, learning environment, technology, and the characteristics of knowledge, skills of students and teachers.

\section{Design}

In designing thematic learning media, the design stage has similarities with designing teaching and learning activities. This activity is a systematic process starting from setting learning objectives, designing teaching and learning scenarios, designing learning tools, designing learning materials and evaluating learning outcomes. The design of this learning media is still conceptual and will underlie the next media development process. At this design stage it can be formulated in the following figure: 


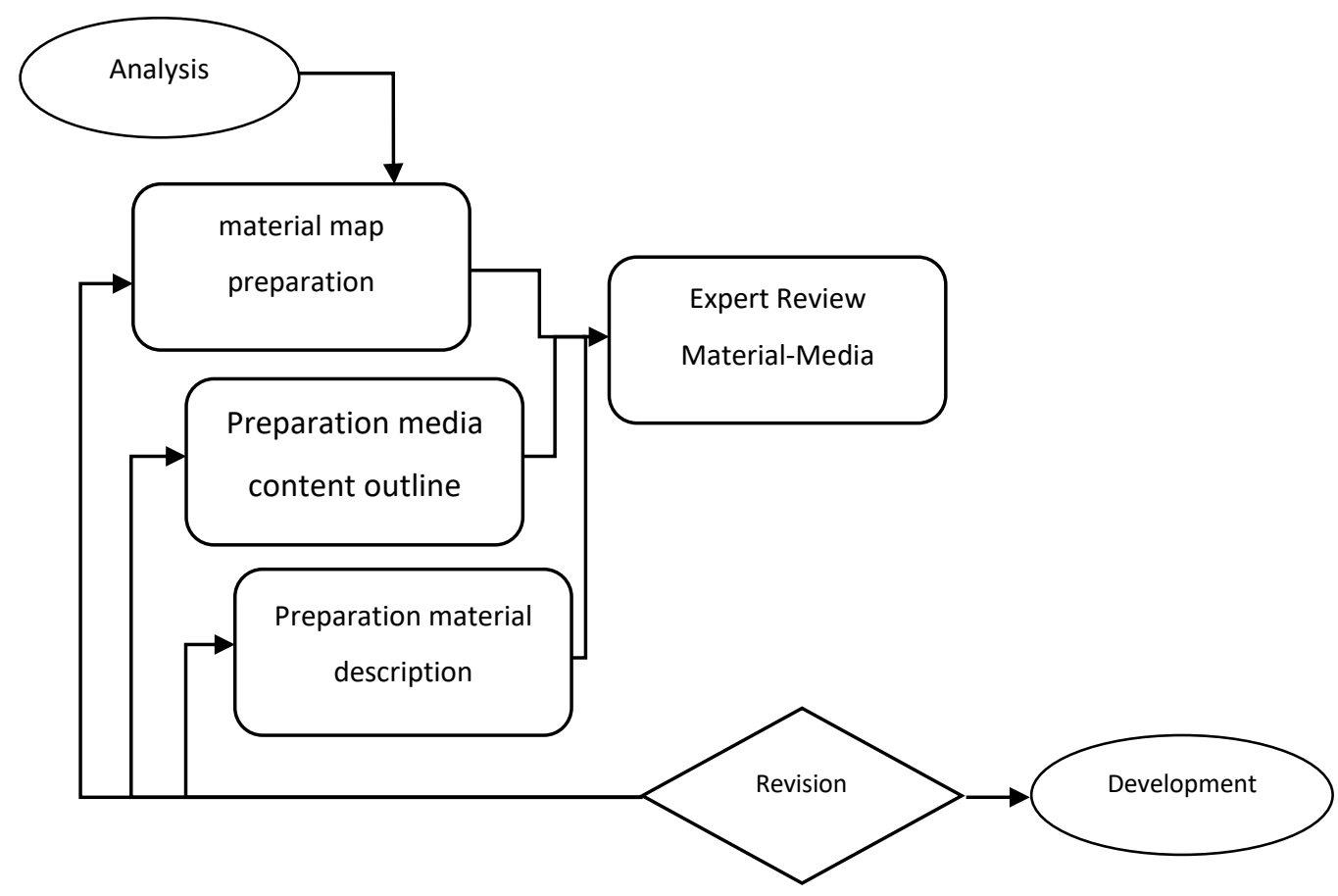

Figure 2 Planning Stage SMART-PEN

\section{Develop}

At this stage the researcher prepares a framework that was previously still conceptual to be realized into a learning media device that is ready to be implemented. As at the design stage, the thematic learning media was made in the development stage. After making learning media, expert and practitioner assessments are carried out to get suggestions for improvements to the learning device plan. After it was implemented, there were several revisions and input from the classroom teacher on the learning media to make it easier and more concrete so that improvements were needed.

The Smart-Pen thematic media has been validated by media experts and materials experts as well as practitioners in schools. with the following table:

Table 1. Smart-Pen Material and Media Validation

\begin{tabular}{cccc}
\hline Validator 1 & Validator 2 & Validator 3 & Validator 4 \\
\hline 94.23 & 91.35 & 98.08 & 96.15 \\
\hline \multicolumn{5}{c}{94.95} \\
\hline
\end{tabular}

Decision making on the validation of the learning model design uses the criteria in table following. 
Table 2. Validation Criteria

\begin{tabular}{ccc}
\hline Percentage $(\%)$ & Validation Criteria & Information \\
\hline $85,01-100,00$ & Verry Valid & Usable but needs minor revision \\
\hline $70,01-85,00$ & Quite Valid & Can be used a little revision \\
\hline $50,01-70,00$ & Less Valid & Can be used with multiple revisions \\
\hline $01,01-50,00$ & Invalid & Cannot be used and still requires consultation \\
\hline Source: $[24]$ & &
\end{tabular}

Based on table 2, it can be categorized that the Smart-Pen thematic media is valid with minor revisions and can be used in learning. The first expert validator said that this media was interesting and could be further developed so that it could be maximized in practicing critical thinking and creativity skills. while the second expert validator said that more exploration was needed to make the media easy for children to use.

Validators from practitioners or teachers convey that this media makes new breakthroughs for students and in accordance with the characteristics of the 2013 curriculum there is an exploration of knowledge and skills developed.

After the validation process, a small-scale trial with 5 students was carried out and it was repaired to be tested for the next stage with a larger scale of 10 children so that it could be implemented in experimental class learning.

\section{Implementation}

At this stage, the implementation of the thematic media design and development was reviewed based on the results of observations of the implementation of learning syntax with the RADEC model to train 4C skills by two observers. Aspects observed were teacher and student activities starting from the introduction, core and closing.

Read

at this stage students are given material in the form of reading or videos to be observed as the first step of learning which is presented on Smart-Pen media in the form of interesting electronic books.

Answer

Next, students are given educational games to provide an initial stimulus in the form of 5 questions related to the material

Discuss

Studentsare invited to discuss on collaborative presentation sheets to express ideas that have been found during discussions with their groups

Explain

In the fourth stage, students are given interactive worksheets to find out the extent of students' mastery of the material on this sheet, there are 21 questions with attractive appearances and designs

Create

In the last stage, students will hone their skills by making projects provided by the teacher. 


\section{Evaluation}

Based on the findings in the field, the 4C skills of the sixth graders of Ar Rahman SD Muhammadiyah Sudagaran Wonosobo as an experimental class with the thematic media Smart Paper Engineering (Smart-Pen) used the RADEC model to train the 4C skills of elementary school students with a score of 4C skills for critical thinking 87.10 which means very good, 80.65 creative value with good criteria.

These results show that the use of smart-pen media is effective to train critical thinking and creative thinking skills. Of course, to achieve maximum results, media and learning models can be developed again.

\section{Conclusion}

The results of the research on Smart Paper Engineering (Smart-Pen) Thematic Media Development Using the Radec Model to Train Critical Thinking Skills students got a score of $87.10 \%$ with very good criteria for developing critical thinking and $80.65 \%$ training creative thinking with good criteria. The impact of Smart-Pen for students are 1) Students have critical thinking skills; 2) Students are more enthusiastic about learning; 3) Students can become creative directors and find specifications for in-depth learning media; 4) Learners can innovate; 5) as a reference and development media for teachers in conducting learning 6) Smart-pen is effectively used in training critical and creative thinking skills.

\section{Acknowledgments}

The author would like to thank the guidance of Subuh Anggoro as a supervisor and friend of postgraduate basic education students at the University of Muhammadiyah Purwokerto, to the Principal and the extended family of SD Muhammadiyah Sudagaran Wonosobo who provided the opportunity to study and research, as well as to his beloved family who gave encouragement and prayers in the process. This research and all parties who helped in the study.

\section{Reference}

[1] AKM dan Implikasinya pada Pembelajaran, P.A.D. PEMBELAJARAN, B.P.D.P.D. PERBUKUAN, and K.P.D. KEBUDAYAAN, Editors. 2020, Pusat Asesmen dan Pembelajaran Balitbang dan Perbukuan Kementrian Pendidikan dan Kebudayaan: Jakarta.

[2] Van Laar, E., et al., The Relation Between 21st Century Skills and Digital Skills: A Systematic Literature Review. 2017. 72: p. 577-588.

[3] Areti, C., A Systematic Literature Review of 21st Century Skills and Competencies in Primary Education. International Journal of Instruction, 2018. 11(3): p. 1-16.

[4] Ridwan, S. Intellectual Capital dan Knowledge Management dalam Inovasi dan Kreasi Media Pembelajaran Berbasis Kemampuan 4C dan Literasi. in International Consortium of Education and Culture Research Studies ICECRS. 2019. ojs.umsida.ac.id.

[5] Merta Dhewa, K., et al., The Development of Higher Order Thinking Skill (Hots) Instrument Assessment in Physics Study. IOSR Journal of Research \& Method in Education (IOSR-JRME), 2017. 7(1): p. 26-32.

[6] Sopandi, W., Sosialisasi dan Workshop Implementasi Model Pembelajaran RADEC Bagi Guru-Guru Pendidikan Dasar dan Menengah [Dissemination and Implementation Workshop of RADEC Learning Models for Primary and Secondary Education Teachers]. Pedagogia: Jurnal Pendidikan, 2019. 8(1): p. 19-34. 
[7] Handayani, H., et al., RADEC: An Alternative Learning Of Higher Order Thinking Skills (HOTs) Students Of Elementary School on Water Cycle. Journal of Physics: Conference Series, 2019. 1351(1): p. 1.

[8] Wibawanto, W., Desain dan Pemrograman Multimedia Pembelajaran Interaktif. 2017, Jember: Penerbit Cerdas Ulet Kreatif.

[9] Samala, A.D., B.R. Fajri, and F. Ranuharja, Desain dan Implementasi Media Pembelajaran Berbasis Mobile Learning Menggunakan Moodle Mobile App. Jurnal Teknologi Informasi Dan Pendidikan, 2019. 12(2): p. 13-20.

[10] Ananda, R. and F. Fadhilaturrahmi, Analisis Kemampuan Guru Sekolah Dasar dalam Implementasi Pembelajaran Tematik di SD. Jurnal Basicedu, 2018. 2(2): p. 11-21.

[11] Syaifuddin, M., Implementasi Pembelajaran Tematik di Kelas 2 SD Negeri Demangan Yogyakarta. Tadris: Jurnal Keguruan dan Ilmu Tarbiyah, 2017. 2(2): p. 139-144.

[12] Ives, R., Paper Engineering \& Pop-ups For Dummies. 2009, Indiana: Wiley Publishing.

[13] Renovita, S., A. Amrullah, and S. Ahmad, Media Video Animasi 3d sebagai Salah Satu Pembelajaran. Cyberpreneurship Innovative and Creative Exact and Social Science, 2018. 4(1): p. 113-124.

[14] Guardia, J.J., et al., Innovation in the teaching-learning process: the case of Kahoot! On the horizon, 2019.

[15] Erviana, V.Y. and L. Fatmawati. Pelatihan Strategi Pembelajaran Berbasis HOTS dan Pengembangan Media Membelajaran dengan Platform Free Bagi Guru SD. in Seminar Nasional Hasil Pengabdian Kepada Masyarakat. 2020.

[16] Budyastomo, A.W., Gim Edukasional untuk Pengenalan Tata Surya. Teknologi: Jurnal Ilmiah Sistem Informasi, 2020. 10(2): p. 55-66.

[17] Pratama, Y.A., W. Sopandi, and Y. Hidayah, RADEC Learning Model (Read-AnswerDiscuss-Explain And Create): The Importance of Building Critical Thinking Skills In Indonesian Context. International Journal for Educational, 2019. 1(2): p. 109-115.

[18] Sopandi, W. The Quality Improvement of Learning Processes and Achievements Through the Read-Answer-Discuss-Explain-and Create Learning Model Implementation. in Proceeding 8th Pedagogy International Seminar 2017: Enhancement of Pedagogy in Cultural Diversity Toward Excellence in Education. 2017.

[19] Zubaidah, S. Mengenal 4C: Learning and innovation skills untuk menghadapi era revolusi industri 4.0. in 2nd Science Education National Conference. 2018.

[20] Mulyatiningsih, E., Riset Terapan Bidang Pendidikan dan Teknik. 1 ed. 2011, Yogyakarta: UNY Press.

[21] Sugiyono, Metode Penelitian Pendidikan (Pendekatan Kuantitatif, Kualitatif, dan R\&D). Vol. 27. 2018, Bandung: Alfabeta.

[22] Arikunto, S., Prosedur Penelitian: Suatu Pendekatan Praktik. Cet. 15 ed. 2013, Jakarta: PT RINEKA CIPTA.

[23] Nurhaifa, I., G. Hamdu, and Y. Suryana, Rubrik Penilaian Kinerja pada Pembelajaran STEM Berbasis Keterampilan 4C. Indonesian Journal of Primary Education, 2020. 4(1): p. 101-110.

[24] Prasetiyo, N.A. and P. Perwiraningtyas, Pengembangan Buku Ajar Berbasis Lingkungan Hidup Pada Mata Kuliah Biologi di Universitas Tribhuwana Tunggadewi. Jurnal Pendidikan Biologi Indonesia, 2017. 3(1): p. 19-27. 